\title{
Perceived value of national wrestlers
}

\author{
Mehtap YILDIZ1 \\ ${ }^{1}$ Necmettin Erbakan Üniversitesi, Ahmet Keleşoğlu Eğitim Fakültesi, Beden Eğitimi ve Spor Bölümü \\ Address Correspondence to M. Yıldiz,e-mail: yildizmehtap77@gmail.com
}

\begin{abstract}
The aim of this research is the goals of the value detectors that we present to the sportsmen of the national wrestlers. In the research, interview method was used in qualitative research companies. The research group consisted of 7 national wrestlers (1 female, 6 male) from Hatay Mustafa Kemal University, Çukurova University and Mersin University in 2015-2016 Education Year. The data were reached through the Personal Information Form (4 questions) and the Semi-Structured Interview Form (5 questions). Content analysis method was used for evaluation of the data. As a result of the research, it has been determined that the most frequently stated values of national wrestlers' opinions about the values they have gained from sports are selfconfidence, respect, obeying rules, cooperation, tolerance, responsibility, ambition, discipline and etc. It is thought that sports gain the human values that are accepted in society and tried to teach to individuals from a very early age.
\end{abstract}

Keywords: National, perception, value, wrestle.

\section{INTRODUCTION}

In interpersonal relations, the concepts of right and wrong are increasingly confused. Individuals within the society are anticipated to show behaviors that are right, fair, respectful to the individual and loves the individual. These behaviors must be in accordance with generally accepted values adopted by society (22).

The value term is the principles that create the desired, undesirable, good and bad judgments about individuals, objects, behaviors, thoughts and beliefs (14). According to Schwartz (26), value is the criteria in which an individual evaluates himself / herself, other individuals and events, and chooses and defines his / her behaviors. Value is a very important part of an individual's character and experience (13). Values are internalized by individuals and constitute the philosophy of common life of societies. In addition, it plays a role not only in the formation of legal norms but also in the establishment of moral behaviors in the society (34). Values act as a bound that lets individuals to connect to each other and to put up with each other (5).
Sport is a crucial tool that allows individuals to develop their characters. Thanks to sports, individuals learn such values; work regularly and disciplined, obey rules, self-confidence, cooperation, tolerance, justice, sportsmanship, patience (19), being in unity and togetherness, assemble for a common purpose, striving for success, apologizing for wrong behaviors. Learning showing respect, appreciation, thanking, courage, friendship, cooperation, cleanliness (21), self-esteem, selfdiscipline, emotion control, non-discrimination, teamwork, entertainment, inclusion (9), health, renewal, social participation, employment, love of the country and nation, competition, win and loss (10).

Successful high-level athletes both in sporting periods and after ending their sporting lives; their lifestyles is being a model for future generations. Simon (29) stated that world famous athletes are considered to be watched by their fans with their style, courtesy, sacrifices, loyalty and courage as well as their excellent sportsmanship.

Sport is one of the most important social environments in which individuals can gain value 
that is accepted by society. Therefore, it is important to determine what values are gained by sports in high-level athletes. It is thought that determining the perceptions of the athletes who have been engaged in sports for many years and reached the level of national athletes are also necessary in the field of sports science. The purpose of this research is to determine the perceptions of national wrestlers on the values they have gained from sports.

\section{MATERIAL \& METHOD}

In the research, phenomenological research approach is used in qualitative research models. Phenomenology research defines the common meaning of the experiences of a few people about a concept and tries to determine the common characteristics of all participants (6). In other words, it focuses on how people perceive the phenomenon, how they feel about it, how they judge it, and how they make sense of it. Thus, the data of the study was obtained by interview method. The interviews were applied to determine the meanings of emotions, thoughts, intentions and events in their lives that were not observed in the participants (23). Interview method is the basic data collection tool in qualitative research and has the flexibility to adapt to different research situations (25).

The research group consisted of 7 national wrestlers (1 female, 6 males) who study in the physical education and sports colleges of Hatay Mustafa Kemal University, Çukurova University and Mersin University in the 2015-2016 Academic Year and determined by the purposive sampling method (37), which are frequently used in qualitative researches. Nicknames were given to the wrestlers that participated into the interview (Table $1)$.

The data were acquired through the Personal Information Form and the Semi-Structured Interview Form prepared by the researcher. In the Personal Information Form, 4 questions including the age, the university and the department where he / she studied, the number of nationalities and the duration of the sports branch, and there are 5 questions that consist of semi-structured openended questions in the interview form, including the concepts of fair play-sportive virtue, trying every way to success and win in the sport, the athlete received the sample with the peculiarities of life, ideas about spiritual values that give strength to in sport competitions, and values gained by sport.
The focus is on internal validity in qualitative researches. In order to increase the internal validity of the interview form, the opinions of three members of the sports sciences field were consulted, and with the help of 2 national athletes selected from the target population, the questions were finalized by pilot research on the sample (33). Five open-ended questions that serve the purpose of the research were applied to national wrestlers by faceto-face interviews. The interviews were held between 14-20 April 2016 with the permission and appointment of the national wrestlers. The interviews lasted between 18-25 minutes.

For ensuring of the validity and reliability of the study, credibility, long-term interaction, depthoriented data collection, expert review and participant confirmation strategies were used (18). Besides, the national wrestlers participated in the research voluntarily, the risks and the confidentiality of the meetings were kept confidential, the data were protected and the findings were reflected objectively and carefully. Berg and Lune (4) describe these processes as ethical dimensions.

As the qualitative data are based on verbal expressions, the main role of the researcher in the analysis process is the elimination of the unrelated sections of the relevant sections of the raw data (1). Content analysis method was used to evaluate the data. Content analysis encapsulates thinking about what data to include in the analysis and what to analyze, as well as how to effectively use the analysis steps and coding tables (4).

Qualitative data were read separately by the researcher and two experts and the process of creating themes was started. As a result of this process, the themes that were agreed and themes were determined. The reliability of the data was calculated by using Miles and Huberman's (1994) Theme / Consensus + Disagreement provided theme X 100 formula (35).

The formula used to measure the harmony between researchers and experts which determines the themes should be $70 \%$ or more. The researchers and experts who tried to determine the harmony between the themes reached a consensus on the 42 / $46 \times 100=91.3$ ratio. 


\section{RESULTS}

Table 1 indicates the age of the national wrestlers

national, number of years they have done this sport participating in the research, number of being

branch and the findings of the interview date.

\begin{tabular}{|c|c|c|c|c|c|}
\hline $\begin{array}{l}\text { Nicknames of } \\
\text { Participants }\end{array}$ & Age & University and Department & $\begin{array}{c}\text { Number of } \\
\text { being National }\end{array}$ & $\begin{array}{l}\text { Number of years } \\
\text { for doing sports }\end{array}$ & $\begin{array}{c}\text { Interview } \\
\text { date }\end{array}$ \\
\hline Mustafa & 18 & $\begin{array}{c}\text { Hatay Mustafa Kemal Uni. } \\
\text { PESC }\end{array}$ & 2 & 6 & 14.04 .2016 \\
\hline Fatma & 23 & $\begin{array}{c}\text { Hatay Mustafa Kemal Uni. } \\
\text { PESC }\end{array}$ & 3 & 10 & 15.04 .2016 \\
\hline Hüseyin & 27 & $\begin{array}{c}\text { Hatay Mustafa Kemal Uni. } \\
\text { PESC }\end{array}$ & 19 & 15 & 16.04 .2016 \\
\hline Burak & 22 & $\begin{array}{l}\text { Mersin Uni. } \\
\text { PESC } \\
\end{array}$ & 3 & 12 & 19.04 .2016 \\
\hline Osman & 21 & $\begin{array}{l}\text { Mersin Uni. } \\
\text { PESC }\end{array}$ & 1 & 9 & 19.04 .2016 \\
\hline Haluk & 21 & $\begin{array}{c}\text { Çukurova Uni. } \\
\text { PESC }\end{array}$ & 4 & 12 & 20.04 .2016 \\
\hline Serdar & 19 & $\begin{array}{c}\text { Çukurova Uni. } \\
\text { PESC }\end{array}$ & 1 & 8 & 20.04 .2016 \\
\hline
\end{tabular}

Table 1, it has been determined that the age range of the research group is between 18 and 27, 3 national athletes according to the university and department status study at Hatay Mustafa Kemal University Physical Education and Sports College (PESC), 2 of them from Mersin University PESC, 2 of them from Çukurova University PESC, according to the number of national athletes with the least national athletes 1 , the most national athletes 19 times been national, according to doing this sport branch it has been wrestling for at least 6 years and maximum 15 years.

Table 2 presents the findings of the national wrestlers' opinions on the concepts of fair play and sportive virtue.

Table 2. Findings of national wrestlers' perceptions of fair play and passive virtue concepts

\begin{tabular}{|c|c|c|c|c|c|c|c|c|}
\hline \multicolumn{9}{|c|}{ Participants } \\
\hline Themes & Mustafa & Fatma & Hüseyin & Burak & Osman & Haluk & Serdar & Frequency \\
\hline Gentlemanship & $\sqrt{ }$ & $\sqrt{ }$ & & & & $\sqrt{ }$ & & 3 \\
\hline Honesty & $\sqrt{ }$ & & & & & & $\sqrt{ }$ & 2 \\
\hline Obeying Rules & $\sqrt{ }$ & & & & & & & 1 \\
\hline Love-Respect & & & $\sqrt{ }$ & $\sqrt{ }$ & & $\sqrt{ }$ & & 3 \\
\hline Focusing on only to Winning & & & & & $\sqrt{ }$ & & & 1 \\
\hline
\end{tabular}

In the Table 2 below themes were reached out:

\section{Gentlemanship}

For the theme of gentleman in the thinking of national wrestlers in terms of fair play and sport virtue Mustafa said "Even if we beat our rival we behave like a gentleman towards them...", Fatma said "The gentleman behaviour that comes to my mind first, when I notice my opponent's injury, I leave the match to the referee."

\section{Love-Respect}

Turk ل Sport Exe 2019; 21(): 58-66

(4) 2019 Faculty of Sport Sciences, Selcuk University
For the theme of love-respect in the national wrestlers' thinking about the concepts of play and sportive virtue Hüseyin said "What comes to my mind are the competitions that have been done in the frame of love-respect.", Burak said "Being respectful and lovely towards rival, trainer, referee.", Haluk said "Showing respect and love towards everyone."

\section{Honesty}

For the theme of honesty, national wrestlers think about the concepts of fair play and sportive virtue Serdar said "Honesty, you have to be honest. My 
opponent did not have a swimsuit before a competition. I was going to get the match, but I gave him my extra swimsuit and I got him back in the game."

In addition to these themes, national wrestlers have to adhere to the rules and not to think about winning only in competitions, and that winning should not be the only goal.

Table 3 presents the findings of the national wrestlers participating in the research about their thoughts about the success of the sport and trying every way to win.

\begin{tabular}{|c|c|c|c|c|c|c|c|c|}
\hline \multicolumn{9}{|c|}{ Participants } \\
\hline Themes & Mustafa & Fatma & Hüseyin & Burak & Osman & Haluk & Serdar & Frequency \\
\hline Struggle with the frame of rules & $\sqrt{ }$ & $\sqrt{ }$ & & $\sqrt{ }$ & $\sqrt{ }$ & & $\sqrt{ }$ & 5 \\
\hline $\begin{array}{c}\text { There should not be unfair } \\
\text { behaviors }\end{array}$ & & $\sqrt{ }$ & & & & $\sqrt{ }$ & & 2 \\
\hline Trying to win deservedly & & & $\sqrt{ }$ & $\sqrt{ }$ & & $\sqrt{ }$ & & 3 \\
\hline
\end{tabular}

In the Table 3 below themes were reached out:

\section{Struggle with the frame of Rules}

In the views of national wrestlers in the struggle for success in sport and in every way to win Mustafa said "We have to do the techniques in the framework of the rules and try every way of technical tactics. We want success in the framework of the rules.", Burak "Everything should be according to certain rules. Winning deservedly is different. Its desire is more than everything", Osman "Every way should be tried by aiming to win without going out of sports rules."

\section{Trying to Win Deservedly}

National wrestlers' success in the sport and trying to win every way to win by trying to win deservedly theme Hüseyin said "This type of thinking athletes go to doping and it is unfair for other athletes. However, every athlete should try to win with his/her own right.", Haluk "Camps, training programs, eating and drinking, such as paying attention to the situation should be tried to win by deserving."
In the views of national wrestlers about unsuccessful movements in sport and in their opinions about trying every way to win Fatma said"Quenching, doping, sportsmen should not be resorted to any unsportsmanlike movements and the basis of the sport should not be destroyed."

Table 4 presents the findings of the thoughts of the national wrestlers participating in the research and their thoughts about the characteristics of the athletes they took as idols.

There Shouldn't be Unfair Behaviors 
Table 4. Findings about the thoughts of national wrestlers about the characteristics of the athletes that they take as idols

\begin{tabular}{|c|c|c|c|c|c|c|c|c|}
\hline \multicolumn{9}{|c|}{ Participants } \\
\hline Themes & Mustafa & Fatma & Hüseyin & Burak & Osman & Haluk & Serdar & Frekans \\
\hline $\begin{array}{l}\text { Struggle under harsh } \\
\text { conditions }\end{array}$ & $\sqrt{ }$ & & & & & & & 1 \\
\hline Discipline & $\sqrt{ }$ & & & & $\sqrt{ }$ & $\sqrt{ }$ & & 3 \\
\hline Success & $\sqrt{ }$ & $\sqrt{ }$ & & & $\sqrt{ }$ & & & 3 \\
\hline Respect & & $\sqrt{ }$ & & & & & & 1 \\
\hline Confidence & & $\sqrt{ }$ & & & & & & 1 \\
\hline Perseverance & & & $\sqrt{ }$ & & & & & 1 \\
\hline Technique & & & & $\sqrt{ }$ & & & & 1 \\
\hline Industriousness & & & & & & & $\sqrt{ }$ & 1 \\
\hline
\end{tabular}

In the Table 4 below themes were reached out:

\section{Discipline}

Discipline theme in the views of the national wrestlers about the characteristics of the athletes that they model with Mustafa said "Being disciplined is one of the effective aspects that has impact on me.", Osman "Working with discipline throughout his/her life.", Haluk "He/She is disciplined, neat, not escaping from a training, careful with the diet program".

\section{Success}

The theme of success in the views of the national wrestlers about the characteristics of the athlete they took as an example Fatma said "I was very impressed by his/her success of the matches..", Osman said "The successes he/she achieved at an early age, his/her ratings were very different from my point of view."

In addition to these themes, national wrestlers stated that they are struggling under difficult conditions and persevering in their opinions on the characteristics of the athletes who are taken as an idol by their lives, respecting everyone, having high self-confidence, hardworking and wrestling techniques are remarkable characteristics.

In Table 5, the findings of the national wrestlers' opinions about the spiritual values giving power to them were included in the research.

Tablo 5. Findings of national wrestlers' thoughts on spiritual values giving power to them in competitions

\begin{tabular}{|c|c|c|c|c|c|c|c|c|}
\hline \multicolumn{9}{|c|}{ Participants } \\
\hline Themes & Mustafa & Fatma & Hüseyin & Burak & Osman & Haluk & Serdar & Frequency \\
\hline Flag & $\sqrt{ }$ & $\sqrt{ }$ & $\sqrt{ }$ & & & & & 3 \\
\hline Independence March & $\sqrt{ }$ & & $\sqrt{ }$ & & & & & 2 \\
\hline Family & & $\sqrt{ }$ & & $\sqrt{ }$ & $\sqrt{ }$ & & $\sqrt{ }$ & 4 \\
\hline Friends & & $\sqrt{ }$ & & & $\sqrt{ }$ & & $\sqrt{ }$ & 3 \\
\hline Motherland & & & $\sqrt{ }$ & & & $\sqrt{ }$ & & 2 \\
\hline Trainer & & & & & $\sqrt{ }$ & & $\sqrt{ }$ & 2 \\
\hline Turkish Nation & & & & & $\sqrt{ }$ & $\sqrt{ }$ & & 2 \\
\hline
\end{tabular}

In the Table 5 below themes were reached out:

National wrestlers' thoughts about the spiritual values that give them power, respectively; family, flag, friends, independence march, homeland,
Turkish Nation, trainer themes are considered to be important spiritual values.

Table 6 indicates the findings of national wrestlers' opinions about the values they have gained from sports. 
Table 6. Findings on the ideas of national wrestlers on the values they have gained from the sport

\begin{tabular}{|c|c|c|c|c|c|c|c|c|}
\hline \multicolumn{9}{|c|}{ Participants } \\
\hline Themes & Mustafa & Fatma & Hüseyin & Burak & Osman & Haluk & Serdar & Frequency \\
\hline Obeying the Rules & $\sqrt{ }$ & $\sqrt{ }$ & $\sqrt{ }$ & & $\sqrt{ }$ & $\sqrt{ }$ & & 5 \\
\hline Discipline & & & $\sqrt{ }$ & $\sqrt{ }$ & $\sqrt{ }$ & & & 3 \\
\hline Kindness & $\sqrt{ }$ & $\sqrt{ }$ & & & & $\sqrt{ }$ & $\sqrt{ }$ & 4 \\
\hline Respect & $\sqrt{ }$ & $\sqrt{ }$ & $\sqrt{ }$ & & $\sqrt{ }$ & $\sqrt{ }$ & $\sqrt{ }$ & 6 \\
\hline Sympathy & $\sqrt{ }$ & & & & & & & 1 \\
\hline Maturing & $\sqrt{ }$ & & & & & & & 1 \\
\hline Gentlemanship & $\sqrt{ }$ & & & & & $\sqrt{ }$ & $\sqrt{ }$ & 1 \\
\hline Confidence & $\sqrt{ }$ & $\sqrt{ }$ & $\sqrt{ }$ & $\sqrt{ }$ & & $\sqrt{ }$ & $\sqrt{ }$ & 6 \\
\hline Collaboration & $\sqrt{ }$ & $\sqrt{ }$ & & & & & & 2 \\
\hline Unity and Solidarity & $\sqrt{ }$ & & $\sqrt{ }$ & & & & & 2 \\
\hline Helping & $\sqrt{ }$ & $\sqrt{ }$ & $\sqrt{ }$ & & & $\sqrt{ }$ & $\sqrt{ }$ & 5 \\
\hline Balanced Diet & $\sqrt{ }$ & & & & & $\sqrt{ }$ & & 2 \\
\hline Responsibility & $\sqrt{ }$ & & & & $\sqrt{ }$ & $\sqrt{ }$ & $\sqrt{ }$ & 4 \\
\hline Health & & $\sqrt{ }$ & & & & & & 1 \\
\hline Adapting to Society & & & $\sqrt{ }$ & & & & $\sqrt{ }$ & 2 \\
\hline Learning the Losing Bliss & & & $\sqrt{ }$ & & & & & 1 \\
\hline Brotherhood & & & $\sqrt{ }$ & & & $\sqrt{ }$ & & 2 \\
\hline Passion & & & & $\sqrt{ }$ & $\sqrt{ }$ & $\sqrt{ }$ & $\sqrt{ }$ & 4 \\
\hline Moral & & & & & $\sqrt{ }$ & & & 1 \\
\hline Equality & & & & & $\sqrt{ }$ & & & 1 \\
\hline Order & & & & & & $\sqrt{ }$ & & 1 \\
\hline Love & & & & & & & $\sqrt{ }$ & 1 \\
\hline Patience & & & & & & & $\sqrt{ }$ & 1 \\
\hline
\end{tabular}

The following themes are reached in Table 6:

\section{Confidence}

In the thoughts of national wrestlers about the values that the sports given them Mustafa said "Sports has given me a lot of self-confidence. If you don't trust before you go to the mat, I've already been defeated in my brain. Improves my feelings and thoughts.", Fatma "It definitely gives people confidence. A human cannot do anything without self-confidence.", Hüseyin "The selfconfidence of the sportsman is very advanced."

\section{Respect}

The theme of respect by national wrestlers regarding the values they have gained Hüseyin said "Sports teaches me the respect for others' rights.", Osman "I learned to act respectfully in society through sports.", Serdar "Sports requires respect and respect among the friends."

\section{Obeying the Rules}

National wrestlers think about the values that sport gives to them according to the obeying the rules theme Mustafa said "Rules in sport are the most basic principles. No success without rules, the way to obey the rules opens the success' door."

\section{Helping}

The theme of helping the national wrestlers in their thoughts about the values they have gained Mustafa said "Sport taught me to help. We reach our goals by helping.", Serdar "You can't do anything alone in sports, it's important to help."

\section{Kindness}

In the thoughts of national wrestlers about the values that the sport gives to them, the theme of tolerance Haluk said "We learn to be tolerant of each other; towards the athletes, the referee, the coach."

\section{Responsibility}

The theme of responsibility for national wrestlers' thoughts on the values they have gained Osman said "Sports lets people to acquire the responsibility feeling."

\section{Passion}

National wrestlers' opinions on the values they gain Burak said "Sport needs to be passionate to achieve goals."

In addition to these themes, national wrestlers, in their views on the values they have gained, have the following responsibilities: discipline, 
cooperation, unity and togetherness, balanced nutrition, adaptation to society, brotherhood, empathy, maturation, gentlemen, health, learning of virtue of loss, morality, equality, order, love and patience themes

\section{DISCUSSION \& CONCLUSION}

Gentlemanship and love-respect themes came to the forefront in the national wrestlers' thinking about the concepts of fair play and sportive virtue. National wrestlers stated that the concept of fair play in them evokes the notions of gentlemanly and love-respect. Besides, national wrestlers stated that they should be honest in the competitions, to be obeyed to the rules and not to focus only on winning. This result can be interpreted that national wrestlers perceive the concept of sportive virtue as a friendly, friendly and honest fight in competitions, to respect their rival, coach, referee, and to respect the rules in any circumstances. Stornes and Ommundsen (30) determined that the sporting levels of the hand-ball players who are in the team sports are high. Kromerova and Šukys (20) have found that young athletes with less experience attach more importance to the value of obeying the rules than athletes with more experience. Kaya (17) emphasizes on the concept of fair play in school sports programs. The contest stated that they had thoughts such as accepting to lose. Freeman et al. (11) found that physical education teachers give importance to sportsmanship and honesty values during teaching.

Contrary to the findings of the research, Kaya (17) found that the students acted with an understanding of winning in the competitions. Sezen (27) determined that professional football players see rule violations as normal behaviors according to amateur players and non-sporting behaviors as smart tactics. Şahin (32) determined that in the competition only to win the value of playing; human values are not considered in sports.

It has been concluded that national wrestlers should have competitions in their opinions on the road to success in sport and to try every way in order to win, to fight to win by winning competitions and not to take part in sports. This can be explained by the fact that national wrestlers believe that it is important to compete in accordance with the rules and that every way should be tried in order to win in sports. It can also be interpreted that national wrestlers act as individuals with the values required by sport. Topan (36) found that female athletes exhibited more respect for rules and management than men. Sezen Balçıkanlı (28) found a significant relationship between empathic tendency and respect for rules and sport in professional football players.

Contrary to the findings of the study, Şahin (32) found that the phenomenon of success in unscientific ways emerged as lost ethical values. Cruz et al. (7) determined that male football players have an attitude of winning against the rules in order to gain advantage of their team.

It is determined that the importance of the struggle, respect, self-confidence, perseverance, diligence, technical skills are considered important in the thoughts of the national wrestlers. This result can be explained as the role of national wrestlers as a role model, to be disciplined, to have a successful sports life, to be respectful to everyone and every situation, to be confident, to be diligent and determined despite all kinds of negative conditions and to be used as a model for wrestling techniques. Jones and Lavallee (16) found that young athletes consider discipline, respect and self-confidence values important in sports. Freeman et al. (11) found that students prioritize the value of success when doing sports. İyem (15) determined that to be a good footballer, it is necessary to spend regular work and labor from a very early age and work discipline is important.

National wrestlers' thoughts about the spiritual values that give them strength in the family, flag, friends, independence march, homeland, trainer and Turkish Nation themes have been seen as important. This situation, especially in national athlete homeland, nation, flag and the National Anthem can be interpreted as the important elements that motivate them. In addition, it can be said that there are important factors in the success of national athletes in their family, friends and coaches who make a sense of belonging. Perenyi (24) determined that sportsmen consider national identity and tradition values vital.

The most frequently stated values of national wrestlers' opinions about the values they have gained by the sport are determined as self-esteem, respect, obeying rules, cooperation, tolerance, responsibility, ambition, discipline. It can be said that national wrestlers think that sport develops the values that should be in every person in themselves and these values are universal values that should be found in every society. Jones and Lavallee (16) 
found that discipline, self-confidence and goalsetting values were important for young athletes. Çiftçi et al. (8) found that scouting improved the values of love, respect, friendship and tolerance. Stran and Curtner-Smith (31) found that the discipline value affects sport education. Cruz et al. (7) determined that equality and justice values are important for male football players. İyem (15) found that professional football players are important for regular and continuous work from a very early age in order to become a good footballer. Sezen Balçıkanlı (28) concludes that in professional football players, the role of play is a positive influence on moral behavior. Gau and James (12) found that moral values are important in demonstration sports. Behets (3) stated that physical education teachers care about the value of social responsibility. Bahadir

\section{REFERENCES}

1. Akarçay Ulutaş D, Akarçay Ö. Nitel veri analizi. In: Sosyal bilimlerde araştırma yöntemleri, Aslan, Ş, ed. Konya: Eğitim, 2018: 423-437.

2. Bahadır Z, Certel Z, Yıldız Ö. Evaluation of life values of candidate teachers of physical education in terms of gender, class and playing sports. World Applied Sciences Journal, 2013; 23 (3): 309-314.

3. Behets D. Value orientations of physical education preservice and inservice teachers. Journal of Teaching in Physical Education, 2001; 20: 144-154.

4. Berg BL, Lune H. Sosyal bilimlerde nitel araştırma yöntemleri. Aydın, H, trans. ed. Konya: Eğitim, 2015.

5. Cebeci S. Toplum ve devlet yapısında değerler eğitiminin rolü (Kırgızistan örneği). Değerler ve Eğitimi-II Sempozyum Bildirileri Kitabı. Kaymakcan, R, Tınaz, N, Altın, ZŞ, Zengin, M, Okudan, AY, Yiğit, H. eds. II. Uluslararası Değerler ve Eğitimi Sempozyumu, 16-18 Kasım 2012, İstanbul: Ertem, 2015: 619-628

6. Creswell JW. Nitel araştırma yöntemleri. Bütün, M, Demir, SB, trans. eds. Ankara: Siyasal, 2018.

7. Cruz J, Boixadós M, Valiente L, Capdevilla L. Prevalent values in young Spanish soccer players. International Review for the Sociology of Sport, 1995; 30 (3-4), 353-371.

8. Çiftçi S, Olaç FT, Aksakal NB, Yaman Ö. Değerler eğitiminde izciliğin yerine ilişkin izci lideri öğretmenlerin görüşleri. Değerler Eğitimi Dergisi (Ek Özel Sayısı), 2015; 13 (29), 415437.

9. Demirhan G. Sportif değerler ve eğitimi. Toplum ve Hekim, 2014; 29 (5), 351-355.

10. Devine C, Telfer H. Beden eğitimi ve spor neden değerlidir? In: Altyapı sporlarında ve beden eğitiminde değerler, Gürpınar B, trans, Whitehead, J, Telfer, H, Lambert, I, eds. Ankara: Nobel Akademik, 2016: 13-33. et al. (2) found that the values of honesty and courage are crucial for physical education teachers.

Contrary to the findings of the research, Şahin (32) is thought to be gained in sports, being honest, being regular and successful. It was determined that the values did not stand out sufficiently.

Consequently, it is thought that sports gain the human values that are accepted in society and tried to teach to individuals from a young age. It should not be ignored that sport is a field that can pioneer to social values which are decreasing day by day in society. Therefore, it should be kept in mind that sport is an important thing for the values which are tried to be gained through the education of individuals in the society. After that, it is recommended to conduct mixed research to compare individual and team spor

11. Freeman $\mathrm{P}$, Leslie A, Leger $\mathrm{H}$, Williams C. Önemli başkalarının değerleri ne kadar önemlidir? In: Altyapı sporlarında ve beden eğitiminde değerler, Gürpınar B, trans, Whitehead, J, Telfer, H, Lambert, J, eds. Ankara: Nobel Akademik, 2016: 178-190

12. Gau L, James JD. A ten-value-type framework associated with spectator sports: A qualitative inquiry. 2013. Retrieved from http://sgo.sagepub.com/content/3/2/2158244013485580.short

13. Gökalp N. Kişi olmanın değeri ve değerlerin kişi olmadaki yeri. Değerler Eğitimi Dergisi, 2014; 12 (27), 123-134.

14. Halstead JM, Taylor JM. Learning and teaching about values: a review of recent research. Cambridge Journal of Education, 2000; 30 (2), 169-202.

15. İyem C. Yeni çalışma etiği ve boş zaman çalışanları: Türkiye'deki profesyonel futbolcular örneği. Doktora Tezi, Sakarya Üniversitesi Sosyal Bilimler Enstitüsü, Sakarya, 2011.

16. Jones MI, Lavallee D. Exploring the life skills needs of British adolescent athletes. Psychology of Sport and Exercise, 2009; 10 (1), 159-167.

17. Kaya S. İlköğretim okul yöneticilerinin, beden eğitimi öğretmenlerinin ve öğrencilerinin okul spor programlarındaki fair play anlayışları: Bolu ili örneği. Yüksek Lisans Tezi, Abant İzzet Baysal Üniversitesi Sosyal Bilimler Enstitüsü, Bolu, 2011.

18. Kılınç E. Nitel araştırmada geçerlilik ve güvenilirlik. In: Sosyal bilimlerde araştırma yöntemleri, Aslan, Ş, ed. Konya: Eğitim, 2018: 409-453.

19. Kirschenbaum H. 100 ways to enhance values and morality in schools and youth settings. Massachusetts: Allyn \& Bacon Company, 1995

20. Kromerova E, Šukys S. Adolescent involvement in sports activities and internalisation of moral values. Baltic Journal of Sport \& Health Sciences, 2016; 1 (100), 22-30. 
21. Öztürk Kuter F, Kuter M. Beden eğitimi ve spor yoluyla değerler eğitimi. Eğitim ve İnsani Bilimler Dergisi: Teori ve Uygulama, 2012; 3 (6), 75-94.

22. Özbek O. Beden eğitimi öğretmenlerinin mesleki etik ilkeleri ve bu ilkelere uyma düzeyleri. Doktora Tezi, Ankara Üniversitesi Eğitim Bilimleri Enstitüsü, Ankara, 2003.

23. Patton MQ. Nitel araştırma ve değerlendirme yöntemleri. Bütün, M, Demir, SB, trans. eds. Ankara: Pegem Akademi, 2018.

24. Perenyi S. Human values of sport participant and nonparticipant Hungarian youth. Doctoral Dissertation, Semmelweis University, Budapest, Hungary, 2010.

25. Punch KF. Sosyal araştırmalara giriş. Bayrak, D, Arslan, HB, Akyüz, Z, trans. Ankara: Siyasal, 2005.

26. Schwartz SH. Universals in the content and structure of values: theoretical advances and empirical tests in 20 countries. In: Advances in Experimental Social Psychology, Zanna, MP, ed. San Diego: Academic, 1992: 1-65.

27. Sezen G. Profesyonel ve amatör futbolcuların fair play anlayışları üzerine bir araştırma. Yüksek Lisans Tezi, Gazi Üniversitesi Sağlık Bilimleri Enstitüsü, Ankara, 2003.

28. Sezen Balçıkanlı G. Profesyonel futbolcuların fair playe yönelik davranışları ile empatik eğilim düzeyleri arasındaki ilişki. Doktora Tezi, Gazi Üniversitesi Sağlık Bilimleri Enstitüsü, Ankara, 2009.
29. Simon RL. Sports, relativism, and moral education. In: Sports ethics: an anthology, Boxill, J, ed. USA: Blackwell, 2003.

30. Stornes T, Ommundsen Y. Achievement goals, motivational climate and sportspersonship: a study of young handball players. Scandinavian Journal of Educational Research, 2004; 48 (2), 205-221

31. Stran M, Curtner-Smith MD. Influence of two preservice teachers' value orientations on their interpretation and delivery of sport education. Sport, Education and Society, 2009; 14 (3), 339-352.

32. Şahin M. Spor eylemlerinde etik değer sorunu. Doktora Tezi, Çukurova Üniversitesi Sağlık Bilimleri Enstitüsü, Adana, 2003

33. Şencan, H. Sosyal ve davranışsal ölçümlerde güvenilirlik ve geçerlilik. Ankara: Seçkin, 2005.

34. Tatlıdil E, Esgin Günder E. Küreselleşen değerlerin eğitim kurumları üzerine etkisi. Değerler Eğitimi Dergisi, 2013; 11 (26), 259-277.

35. Tavşancıl E, Aslan E. İçerik analizi ve uygulama örnekleri. İstanbul: Epsilon, 2001.

36. Topan A. Ortaöğretim kurumlarında okullar arası futbol müsabakalarına katılan öğrencilerin fair play anlayışlarının kulüp deneyimlerine göre incelenmesi. Yüksek Lisans Tezi, Gazi Üniversitesi Eğitim Bilimleri Enstitüsü, Ankara, 2011.

37. Yıldırım A, Simşek H. Sosyal bilimlerde nitel araștırma yöntemleri. Ankara: Seçkin, 2006 